\title{
Evaluation of Powerhouse Cavern for the SachKhas Hydroelectric Project in Himachal, India
}

\author{
Ajender Rathore and Dr. Krishna Kanta Panthi
}

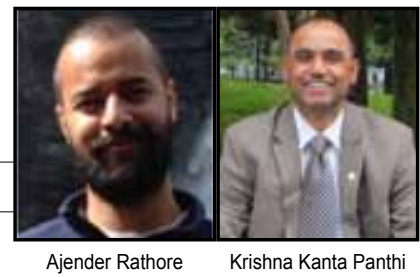

Abstract: Evaluation of an underground powerhouse cavern's stability is a challenging task and needs to be carried out carefully by taking care of its location, orientation and dimensioning. This article deals with the stability evaluation of a large underground powerhouse cavern, which is located at the toe of the valley side slope where the depth varies between $59 \mathrm{~m}$ (minimum) and $70 \mathrm{~m}$ (maximum). The planned powerhouse cavern has a dimension consisting $130 \mathrm{~m}$ length, $23 \mathrm{~m}$ wide and $48 \mathrm{~m}$ high. The manuscript evaluates the extent of pre-construction phase engineering geological investigations of the project, discusses on the selection of input parameters and carries out assessment on the displacement conditions at the cavern and also assesses the extent of yielded zone at the toe slope. Finally, recommendations are suggested on the location and orientation of the powerhouse cavern, uncertainties involved in numerical analysis and boundary conditions for 2D and 3D models under gravitational field stress.

Keywords: Hydroelectric project, Powerhouse cavern, sachkhas, India.

\section{Introduction}

Droduction of renewable energy is a politically, Pocially and environmentally supported trend at present. Energy generated through hydropower facilities to add renewal energy in the market and fullfill possible time lag between production and consumptions. One such possibility lies in the development of run-of-the-river projects with daily or weekly regulation possibilities. Therefore, the number of such run-of-the-river schemes under construction and at planning stage is on the rise. Locating the machines and transformers in an underground cavern is the most common practice around the world and is considered an economic design and environmentally friendly solution (Nilsen and Thidemann, 1993). The importance of underground caverns increases by manifold as per security and strategic point of view, which is the case in all the projects under consideration in northern Himalayan region of India. where rock mass is heavily influenced with active tectonic movement (Panthi, 2012). Many large caverns have been constructed in past decades in the Himalaya. At pre-feasibility phase, the experience, methodology developed (Empirical, analytical and numerical method) and data from full scale experiments in previous projects should be used to validate the design of planned cavern and minimize the risk. This article deals with a specific type of underground cavern design problem, namely stability assessment of large underground opening located at the toe slope having relatively low rock cover. It assesses and compares the displacement of cavern walls and extent of yield zone to toe slope based on the data collected from pre-construction phase engineering geological investigations. Based on the analysis, recommendations are made in the location and orientation of powerhouse cavern. Uncertainties involved in numerical analysis and boundary conditions for $2 \mathrm{D} \& 3 \mathrm{D}$ models under gravitational stress field are also highlighted.

Evaluation on the stability condition of an underground powerhouse cavern is a challenging issue from rock mechanics point of view. Location, orientation, size of the cavern, complexity access tunnels and geological conditions are some important issues other challenges increase e $x$ p o n e n t i a lly while planning $\mathrm{u} n \mathrm{~d}$ e $\mathrm{r}$ g r o u n d excavation Himalayan region

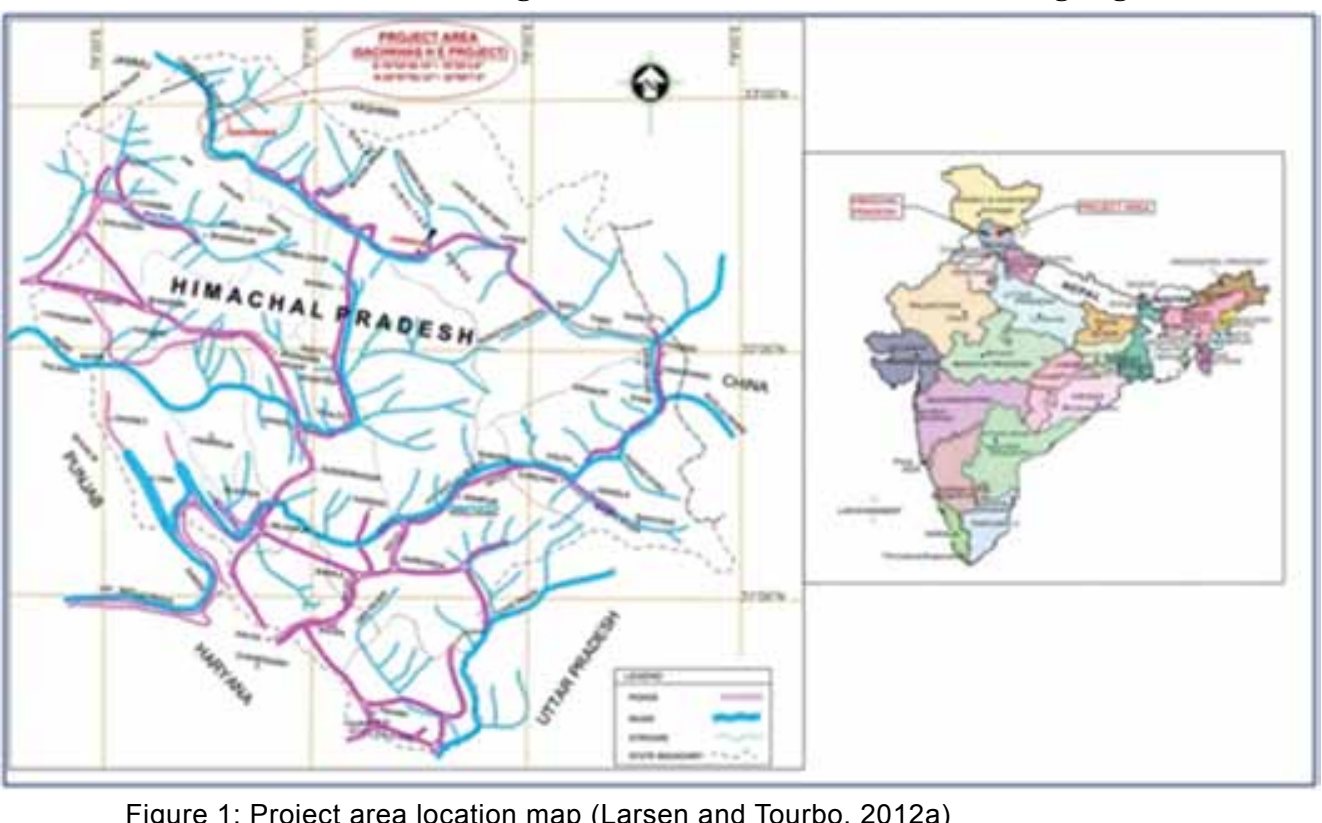

Figure 1: Project area location map (Larsen and Tourbo, 2012a) 


\section{SachKhas Hydroelectric Project}

\section{Brief about the project}

Planned SachKhas hydroelectric project (267 MW) is envisaged as a dam-toe scheme with dam and underground powerhouse located on Chenab river in the Pangi valley of Himachal Pradesh (Larsen and Tourbo, 2012a) and lies at an elevations ranging from $2149 \mathrm{~m}$ to $2219 \mathrm{~m}$ asl (Figure 1).

\section{Project geology}

SachKhas Project area constitutes a part of the Pangi Valley and is characterized by rugged terrain comprising high ranges, deep valleys, escarpments and cliff faces. The area constitutes a part of great Himalayan range, older folded cover sequence and crystalline complex over printed by Himalayan fold thrust movement, covering a stretch of ChandraBhaga Valley. The altitude of the area varies from $2150 \mathrm{~m}$ and 6000m. Project area falls in the Tethyan Himalayas having Higher Himalayan Crystalline Sequences as basement, which is extended from Pangi Valley, Chamba in the northwest to Kinnaur in the southeast (Larsen and Tourbo, 2012b). The project geology belongs to Precambrian Chlorite biotite Zone as shown in Figure 2.

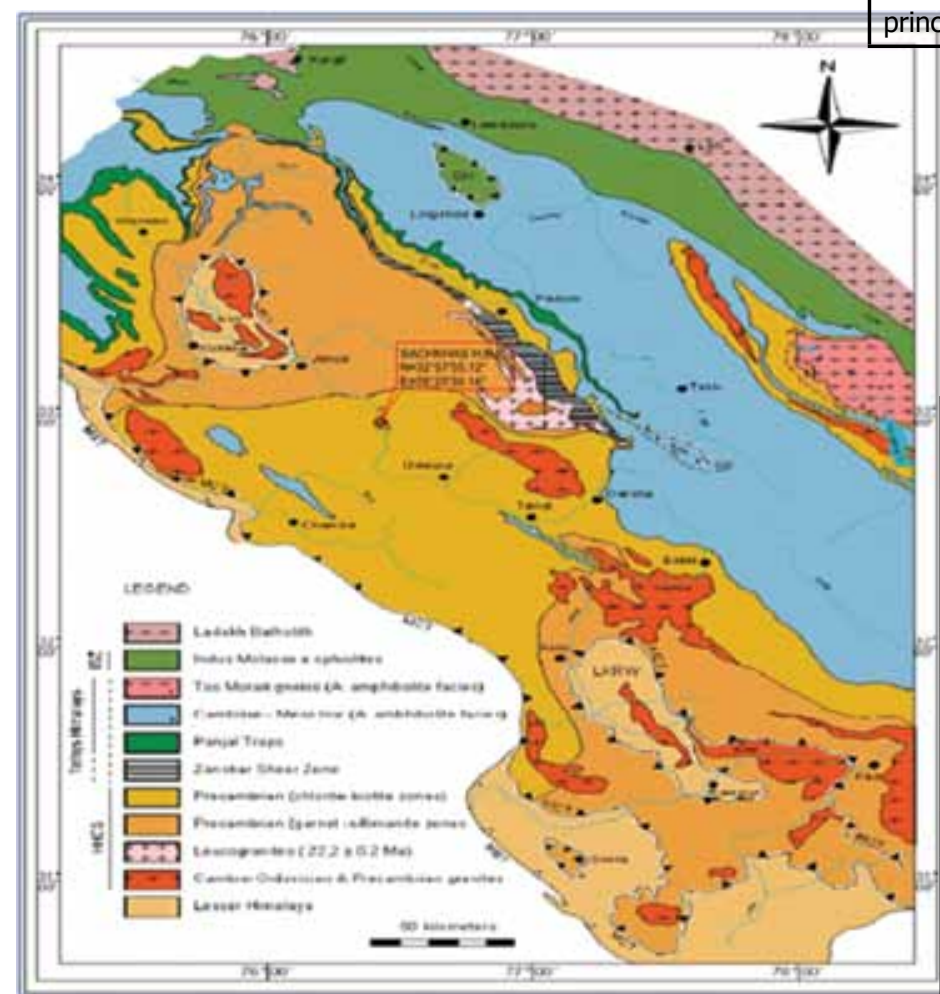

Figure 2. Regional Geological map of Chamba Basin with marked project location (Larsen and Tourbo, 2012b).

The project area is in seismically active regions of the Himalayas. It is continuously under stress and has been experiencing frequent crustal adjustment since the last phase of the Himalayan Orogeny. The rock mass encountered in the drift and in the drill holes are hard and fresh, grey color quartzite, diamictite and phyllite interbands with two plus random joint sets. The proposed powerhouse cavern is likely to encounter fresh and hard quartzite (55\% to $60 \%$ ), diamictite and phyllitic quartzite (30\% to $35 \%$ ) in 80 to $85 \%$ reach, phyllite in $10 \%$ reach and sheared and shattered rock mass in $5 \%$ reach (Larsen and Toubro, 2012b). The underground cavern will be located in grey quartzite, diamictite and phyllitic quartzite bands. The foliation strikes at $\mathrm{N}_{125} \mathrm{E}$ and has dip with 35 - 76 degrees' south-west.

\section{In-situ stress and rock mechanical properties}

The project is located in seismically active western Himalayan region, which is continuously under stress and experiencing frequent crustal adjustment. The in-situ stress measurement in the powerhouse cavern area was done by hydraulic fracturing test. In-situ stress measurement result at power house site is shown in Table 1.

\begin{tabular}{|c|c|c|}
\hline Results & $\begin{array}{l}\text { Values } \\
\text { (MPa) }\end{array}$ & Remarks \\
\hline $\begin{array}{l}\text { In-situ Vertical } \\
\text { Stress ( } \sigma v)\end{array}$ & $1.60-2.04$ & $\begin{array}{l}\text { Based on overburden } \\
\text { range from } 59 m-75 m\end{array}$ \\
\hline $\begin{array}{l}\text { Maximum Horizon- } \\
\text { tal principal stress } \\
(\sigma \mathrm{H})\end{array}$ & 10 & $\begin{array}{l}\text { Orientation of } \sigma \mathrm{H} \text { varies } \\
\mathrm{N} 50^{\circ} \mathrm{E} \text { to } \mathrm{N} 86^{\circ} \mathrm{E} \text {. }\end{array}$ \\
\hline $\begin{array}{l}\text { Minimum Horizontal } \\
\text { principal stress ( } \sigma \mathrm{h})\end{array}$ & 5.88 & \\
\hline
\end{tabular}

Table 1: In-situ stresses at power house site (AECS, 2014).

Rock core samples from different bore holes of SachKhas project were collected and transported to laboratory for carrying out test on the mechanical properties of intact rock. The results of such tests are presented in Table 2.

\begin{tabular}{|l|l|c|c|}
\hline \multicolumn{1}{|c|}{ Tests } & & Values & Units \\
\hline \multirow{4}{*}{ Index Tests } & Bulk Density & 2.72 & $\mathrm{t} / \mathrm{m3}$ \\
\cline { 2 - 4 } & $\begin{array}{l}\text { Water Content at } \\
\text { saturation }\end{array}$ & $0.20-0.32$ & $\%$ \\
\cline { 2 - 4 } & Porosity & 0.51 & $\%$ \\
\hline $\begin{array}{l}\text { Uniaxial } \\
\text { Compressive } \\
\text { Strength }\end{array}$ & Dry Condition & $54-85$ & $\mathrm{MPa}$ \\
\cline { 2 - 4 } & Saturated condition & $53-83$ & $\mathrm{MPa}$ \\
\hline Tensile Strength & - & $10-13$ & $\mathrm{MPa}$ \\
\hline $\begin{array}{l}\text { Modulus of } \\
\text { Elasticity }\end{array}$ & - & $45-67$ & $\mathrm{GPA}$ \\
\hline Poisson's Ratio & - & 0.20 & - \\
\hline Cohesion (c) & - & $5-10$ & $\mathrm{MPa}$ \\
\hline $\begin{array}{l}\text { Friction angle } \\
(\Phi)\end{array}$ & - & $46-51$ & Degree \\
\hline
\end{tabular}

Table 2: Laboratory test results (Larsen and Tourbo, 2012a \& 2012b). 


\section{Stability Assessment}

Stability assessment is done by different methods depending upon the type of failure. There are two distinct types of failure that occur in the roof and wall of the underground cavern; i.e. structurally controlled instability (Hammett and Hoek, 1981; Hoek 2007) and stress induced instability (Nilsen and Palmström, 2000; Nilsen and Thidemann, 1993). To carry out stability assessment both conventional analysis and numerical modelling was carried out for the powerhouse cavern.

\section{Conventional methods}

Predicting stability of cavern associated to insitu stress is very important. Analytical approach of Kirsch's equation is used to calculate tangential stress condition in the cavern and the calculated results are shown in Table 3. Hoek and Brown (1980) suggested empirical approach to calculate the magnitude of tangential stress in roof and wall was also used (Table 4).

\begin{tabular}{|l|l|l|}
\hline$\sigma 1[\mathrm{MPa}]$ & $\sigma 3[\mathrm{MPa}]$ & $\sigma \theta \max [\mathrm{MPa}]$ \\
\hline $5.91-6.97$ & $1.60-2.04$ & $16.13-18.87$ \\
\hline
\end{tabular}

Table 3: Maximum tangential stress on the cavern contour based on Kirsch's equations.

\begin{tabular}{|c|c|c|c|c|c|}
\hline $\mathbf{A}$ & $\mathbf{B}$ & $\mathbf{k}$ & $\boldsymbol{\sigma z}[\mathrm{MPa}]$ & $\begin{array}{c}\boldsymbol{\sigma \theta r} \\
{[\mathrm{MPa}]}\end{array}$ & $\boldsymbol{\sigma \theta \mathbf { w } [ \mathrm { MPa } ]}$ \\
\hline 4 & 1.5 & $3.7-3.4$ & $1.60-2.04$ & $\begin{array}{c}22.08- \\
25.07\end{array}$ & $\begin{array}{c}(-3.52)- \\
(-3.87)\end{array}$ \\
\hline
\end{tabular}

Table 4: Tangential stress in roof and walls calculated from the empirical method from Hoek and Brown (1980).

The rock mass classification systems such as Q-system introduced by Barton et at (1974), modified RMR introduced by Bieniawaski (1989) and GSI introduced by Hoek (1994) are common empirical methods that can be used to assess the quality of rock mass and predict rock support need for the underground cavern, in particular to estimate rock support requirement during planning phase of the project. Table 5 and Table 6 give rock mass quality that is assumed to be met in the underground cavern.

\begin{tabular}{|l|c|c|}
\hline \multicolumn{1}{|c|}{ Rock Type } & $\begin{array}{c}\text { \% } \\
\text { reach }\end{array}$ & $\begin{array}{c}\text { Rock mass Qual- } \\
\text { ity Index (Q) }\end{array}$ \\
\hline Fresh and hard quartzite & $55-60$ & \multirow{2}{*}{$7.8-3.6$} \\
\hline Diamictite \& phyllitic quartzite & $30-35$ & \\
\cline { 1 - 2 } Phyllite & $5-10$ & $1.6-<0.5$ \\
\hline
\end{tabular}

Table 5: Rock mass quality in the area of the powerhouse complex from the Q-system

\begin{tabular}{|c|c|c|c|}
\hline System & Value & Rock Class & Description \\
\hline GSI & $48-58$ & Blocky & Fair Rock \\
\hline RMR & $53-63$ & III & Fair Rock \\
\hline
\end{tabular}

Table 6: Rock mass quality from RMR and GSI values used in Empirical and numerical analysis.
RMR system recommends systematic bolts with $4 \mathrm{~m}$ long and spaced at $1.5-2 \mathrm{~m}$ in crown and walls with wire mesh in crown. However, this recommendation is for an underground opening with 10m diameter. Therefore, support chart given in Q-system is used to preliminarily define the rock support needed for the Cavern (Table 7).

\begin{tabular}{|c|c|c|c|c|}
\hline & & $\begin{array}{l}\text { Span } \\
\text { /ESR }\end{array}$ & $\begin{array}{c}\text { Correction } \\
\text { for wall } \\
\text { support }\end{array}$ & Support \\
\hline \multirow{2}{*}{ Roof } & Fair & \multirow{2}{*}{23} & \multirow{2}{*}{ - } & $\begin{array}{l}6 \mathrm{~m} \text { bolts, c/c } 2.0 \mathrm{~m} \text {. } \\
\mathrm{E}=500 \mathrm{~J} \text { shotcrete: } 7 \mathrm{~cm}\end{array}$ \\
\hline & Poor & & & $\begin{array}{l}6 \mathrm{~m} \text { bolts, } \mathrm{c} / \mathrm{c} 1.7 \mathrm{~m} . \\
\mathrm{E}=700 \mathrm{~J} \text { shotcrete: } 12 \mathrm{~cm}\end{array}$ \\
\hline \multirow{2}{*}{ Wall } & Fair & \multirow{2}{*}{48} & \multirow{2}{*}{2.5} & $\begin{array}{l}10 \mathrm{~m} \text { bolts, c/c } 2.5 \mathrm{~m} \text {. } \\
\mathrm{E}=700 \mathrm{~J} \text { shotcrete: } 7 \mathrm{~cm}\end{array}$ \\
\hline & Poor & & & $\begin{array}{l}10 \mathrm{~m} \text { bolts, c/c } 2.0 \mathrm{~m} \text {. } \\
\mathrm{E}=700 \mathrm{~J} \text { shotcrete: } 12 \mathrm{~cm}\end{array}$ \\
\hline
\end{tabular}

Table 7: Recommended support from the $Q$ system.

\section{Unwedge analysis}

In the analysis and detailed modelling of the SachKhas HEP powerhouse cavern the numerical methods such as Unwedge, RS-2D and RS-3D software have been used.

The required jointing parameters for structurally controlled instability analysis are presented in Figure 3. The longitudinal axis of the cavern is orientated at $\mathrm{N} 55^{\circ} \mathrm{E}$ and the orientation of foliation is $\mathrm{N} 125^{\circ} \mathrm{E}$ and has dip direction $35^{\circ}-76^{\circ} \mathrm{SW}$. In addition, there exist two other cross joint sets as indicated in Figure 3.

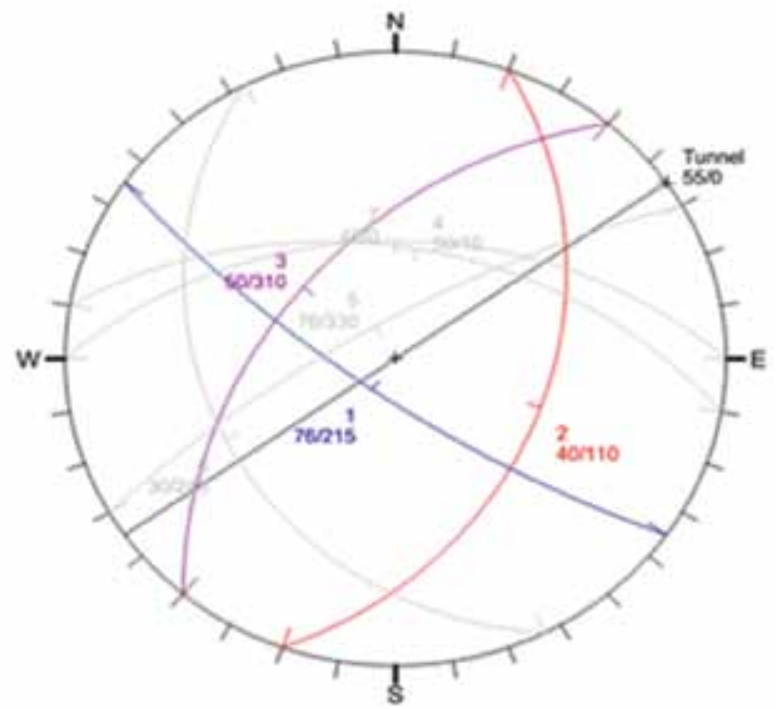

Figure 3: Stereographic projection of jointing conditions with cavern alignment.

Considering uncertainty related to joint orientation, engineering geological properties and cohesion, probabilistic Unwedge analysis is performed. The potentials results on the most critical wedges are based on the finding from maximum support pressure required, maximum wedge depth, 
and minimum factor of safety and probability of failure. Certain results show very critical values, however, the cumulative probability of such critical values is very low. Hence, critical values with very low cumulative probability are used to design support system.

Unwedge result shows maximum required support pressure of $0.026 \mathrm{MPa}$, maximum wedge depth of $5.8 \mathrm{~m}$ and wedge weight in the roof ranges from between 0.066 and $0.147 \mathrm{MN}$. Figure 4 shows minimum factor of safety for the wedge failure on the roof of the cavern.

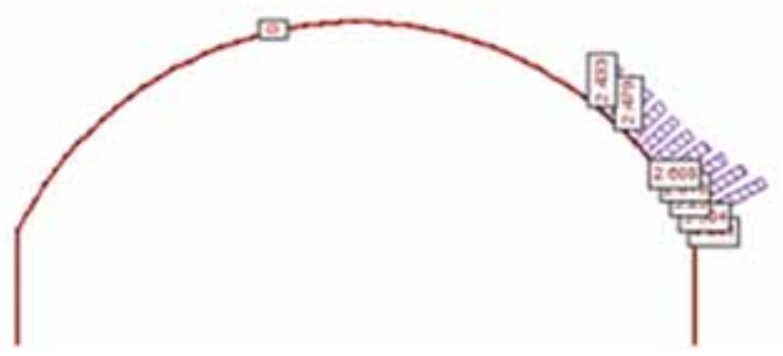

Figure 4: Results of Unwedge on minimum factor of safety at each segment.

Figure 5 shows probability of failure for each segment that was analysed, which is the ratio of the number of failed wedges and the number of samples.

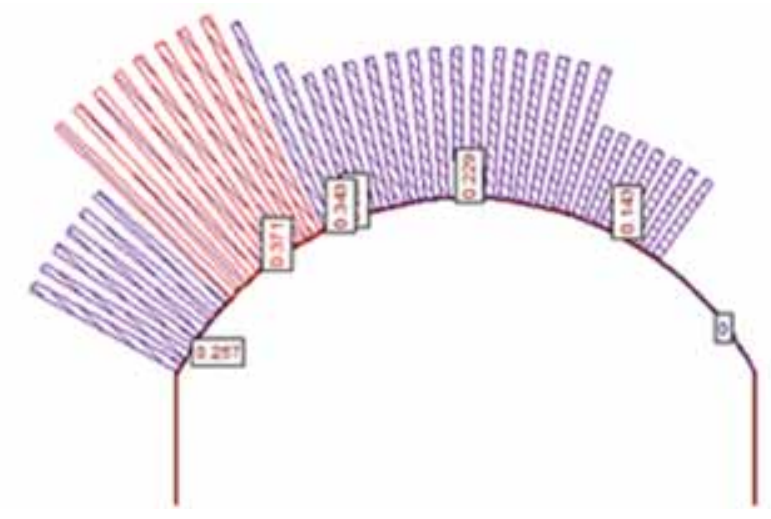

rock bolt support system design in the underground cavern before moving with stress induced instability analysis. Generally, in the design of an underground infrastructure support system, a combined method of rock bolt and shotcrete is applied.

The application of rock bolts increased the factor of safety of the most critical wedges and decreased the probability of failure, which confirms the effectiveness of applied rock bolts.

\section{RS-2D and RS-3D analysis}

In the numerical modelling, a finite element software package was used. RS-2D and 3D represent both two-dimensional and three-dimensional finite element programs used for rock engineering application where multi stage and complex models can be created and analysed quickly. Modelling is carried out as plane stain analysis using Gaussian eliminator as solver type. Both elastic and plastic material properties are applied in the analysis. Redistribution of stresses and strength factor of material was analysed using elastic material. Displacement and rock mass failure was examined using plastic material, which allows the material to yield. Sensitivity analysis was done to check the influence of input parameters on the results.

In the numerical analysis, input parameters of the model and support system are prerequisites. Table 9, Table 10, Table 11, Table 12, Table 13 and Table 14 show inputs for in-situ stress condition including locked in stresses, material properties, rock mass properties, residual rock mass parameters, rock bolt properties and support properties used in numerical modelling.

\begin{tabular}{|c|c|c|}
\hline $\boldsymbol{\sigma 1}(\mathbf{M P a})$ & $\boldsymbol{\sigma 2}(\mathbf{M P a})$ & $\boldsymbol{\sigma 3}(\mathbf{M P a})$ \\
\hline $\begin{array}{c}9.42 \\
\text { (out of plane) }\end{array}$ & $\begin{array}{c}6.44 \\
\text { (in plane) }\end{array}$ & $\begin{array}{c}1.82 \\
\text { (in plane) }\end{array}$ \\
\hline
\end{tabular}

Table 9: Stress situation applied in the numerical model in RS2D and RS-3D (AECS, 2014).

Figure 5: Results of Unwedge on probability of failure for each segment.

\begin{tabular}{|c|c|c|c|c|c|c|}
\hline Location & Type & $\begin{array}{c}\text { Length* } \\
\mathbf{( m )}\end{array}$ & $\begin{array}{c}\text { Spacing } \\
\mathbf{( m )}\end{array}$ & $\begin{array}{c}\text { Diameter } \\
\mathbf{( m m )}\end{array}$ & $\begin{array}{c}\text { Tensile } \\
\text { Capacity (MN) }\end{array}$ & $\begin{array}{c}\text { Yield Strength } \\
\text { (MN) }\end{array}$ \\
\hline Roof & Grouted Dowel & 6 & $1.5 \times 1.5$ & 21.7 & 0.25 & 0.14 \\
\hline
\end{tabular}

Table 8: Rock bolt properties applied in Unwedge model (DSI, 2016)

The design parameters of the rock bolt in the roof and the wall of the powerhouse cavern are determined on the basis of relative operational mechanism as suggested by Gharavi and Shafienzadeh (2008). The parameters considered consist bolt length, bolt spacing, support pressure on the bolt, bolt load, bolt diameter and load capacity of each boalt (Table 8). The achieved results define preliminary

\begin{tabular}{|l|l|}
\hline \multicolumn{1}{|c|}{ Parameters } & \multicolumn{1}{c|}{ Value } \\
\hline UCS & $83.02(\mathrm{MPa})$ \\
\hline E-Modulus & $67.96(\mathrm{GPa})$ \\
\hline Poisson's ratio & 0.20 \\
\hline GSI & 58 \\
\hline
\end{tabular}

Table 10: Locked in stresses calculated from principal stresses in the Power house cavern area. 


\begin{tabular}{|c|c|}
\hline \multicolumn{2}{|c|}{ Locked in Stress } \\
\hline In Plane & Out of plane \\
\hline 5.98 & 8.96 \\
\hline 7.64 & 7.30 \\
\hline
\end{tabular}

Table 11: Material properties obtained from laboratory tests and field mapping (Larsen and Tourbo, 2012b).

\begin{tabular}{|c|c|c|}
\hline Parameter & Undisturbed zone & Disturbed Zone \\
\hline $\mathrm{mb}$ & 4.46 & 2.70 \\
\hline $\mathrm{s}$ & 0.0094 & 0.0036 \\
\hline $\mathrm{a}$ & 0.503 & 0.503 \\
\hline Dilation & 0 & 0.05 \\
\hline Erm $(\mathrm{GPa})$ & 32.25 & 16.47 \\
\hline
\end{tabular}

Table 12: Rock mass properties applied in the numerical model

\begin{tabular}{|c|c|c|}
\hline Parameter & Undisturbed zone & Disturbed Zone \\
\hline $\mathrm{mr}$ & 1.47 & 0.38 \\
\hline $\mathrm{Sr}$ & 0.0003 & 0.000015 \\
\hline $\mathrm{Ar}$ & 0.53 & 0.55 \\
\hline
\end{tabular}

Table 13: Residual rock mass parameters applied in the numerical model.

\begin{tabular}{|c|c|c|c|c|c|c|}
\hline Location & Type & $\begin{array}{c}\text { Length } \\
(\mathbf{m})\end{array}$ & $\begin{array}{c}\text { Spacing } \\
\mathbf{( m )}\end{array}$ & $\begin{array}{c}\text { Diameter } \\
\mathbf{( m m )}\end{array}$ & $\begin{array}{c}\text { Tensile } \\
\text { Capacity (MN) }\end{array}$ & $\begin{array}{c}\text { Bolt Modulus } \\
\text { (GPa) }\end{array}$ \\
\hline Roof/ wall & $\begin{array}{c}\text { Fully bonded } \\
\text { (CT-bolt) }\end{array}$ & $6 / 10$ & $1.5 \times 1.5$ & $33(1)$ & $0.38(1)$ & $200(2)$ \\
\hline
\end{tabular}

Table 14: Rock Bolt properties applied in the model

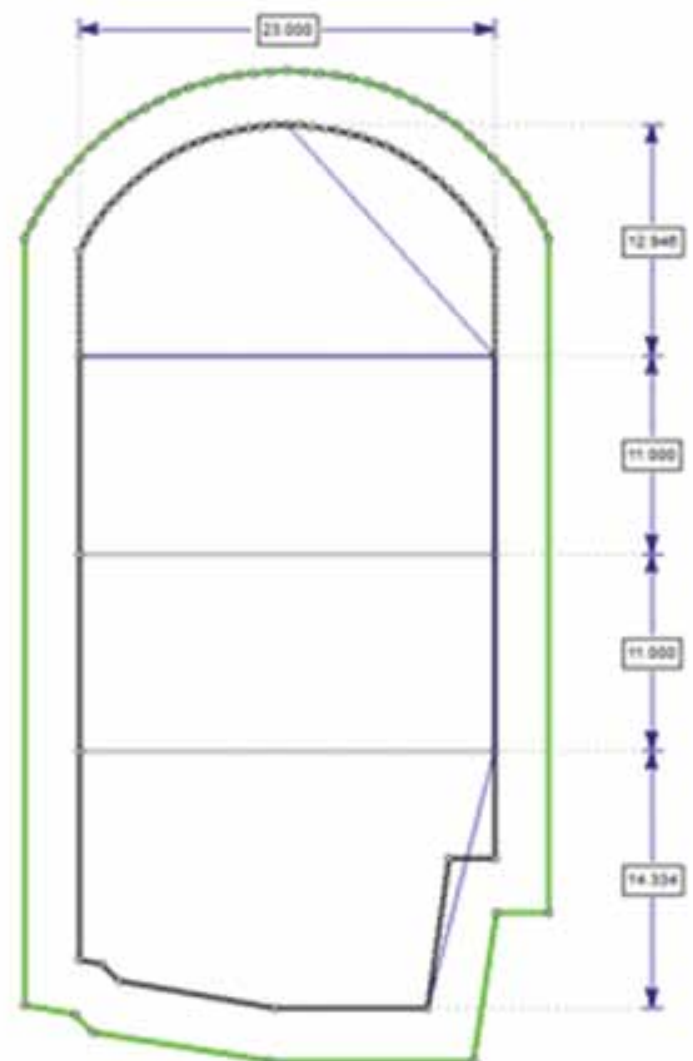

Figure 6: Cavern profile and excavation stages (RS-2D and RS-3D).
The modelling of rock support consisting shotcrete with $15 \mathrm{~cm}$ thick in the roof and $12 \mathrm{~cm}$ thick in the walls and systematic bolt was considered installed immediately after excavation. To simulate shotcrete, standard beam liner principle was used, which considers flexural rigidity (resistance to bending). Timoshenko beam formulation was used for beam elements to account for transverse shear deformation effects. The Estimated elasticity modulus and poison's ration for the shotcrete was $30 \mathrm{GPa}$ and 0.2 , respectively. Estimated other mechanical properties such as compressive strength, residual compressive strength and peak tensile strength were $35 \mathrm{MPa}, 5 \mathrm{MPa}$ and $5 \mathrm{MPa}$, respectively. In general, large scale caverns are excavated in several stages. The scope of performing this task is to find overall stability. Hence, excavation stages have been reduced as compared to the actual excavation plan, which is shown Figure 6.

In $2 \mathrm{D}$ numerical analysis has shown that the maximum tangential stress ( $\sigma \theta \max )$ in the periphery of the cavern of $23.04 \mathrm{MPa}$ and the ratio between the maximum tangential stress and uniaxial compressive strength ( $\sigma \theta \max / \mathrm{UCS})$ of 0.28 , which is favourable condition and no spalling may occur. In addition, negative stresses are generated at the cavern wall and crest of slope, which may cause some stability problem due to tensional cracks at crest of the slope resulting in minor shear failure. According to Hoek and Brown (1980) once such tensile failure occurs in slopes having weak rock mass these are not a big cause of concern as they are local in nature since there will be a stress relief and re-establishment of equilibrium in the changed environment. However, tension due to negative stresses might cause some stability problems in caverns.

A plastic model was also analysed to assess the degree of damage when the material was allowed to yield. Figure 7 shows the extent of yielded elements along the periphery of the powerhouse cavern. It was observed that most of the deformation was concentrated in the cavern wall and the maximum deformation registered by the modelling was $50 \mathrm{~mm}$, which may be considered acceptable and can easily be controlled by the recommended support system. It was noticed that some bolts and shotcrete liner elements yielded in the disturbed zones indicating that the applied support in the model is active and in function. The tensile failure observed in the applied support was believed to be due to increased deformation in the cavern wall as the cavern has relatively large span (23m) and relatively high horizontal stresses.

RS-3D analysis uses similar parameters as of RS2D. Model setup and input data used were mostly same apart from mesh and displacement properties. The model result indicated maximum tangential stress of $24.84 \mathrm{MPa}$ and ratio between the maximum tangential stress and uniaxial compressive strength 
of 0.30 , which is similar to that of RS-2D analysis. The depth of brittle failure and extent of yielded elements were more confined and less critical compared to 2D numerical analysis results (Figure 8).

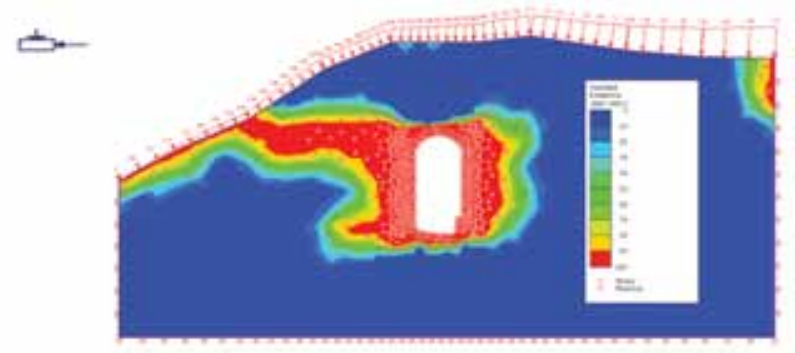

Figure 7: Analysis results on yielded elements in an unsupported cavern. levels of almost $1 \%$ or greater are signs for onset of instability and hence demand for suitable rock support (Hoek, 2001). The deformation observed at the cavern was within acceptable limit. Hoek and Moy (1993) have discussed about the yielded zone of powerhouse caverns located close to the toe slope and gave recommendations to adjust the rock support based on the actual stability condition during cavern excavation. Similarly, all yielded bolt elements were restrained within the disturbed zone, which constitutes $1 / 2$ to $1 / 3$ of rock bolt lengths in cavern roof and walls. This is not considered as a critical state for the stability of the caverns (Panthi, 2016). Very limited shotcrete elements were yielded, which may be due to assumed high compressive strength and high horizontal compressions stresses.

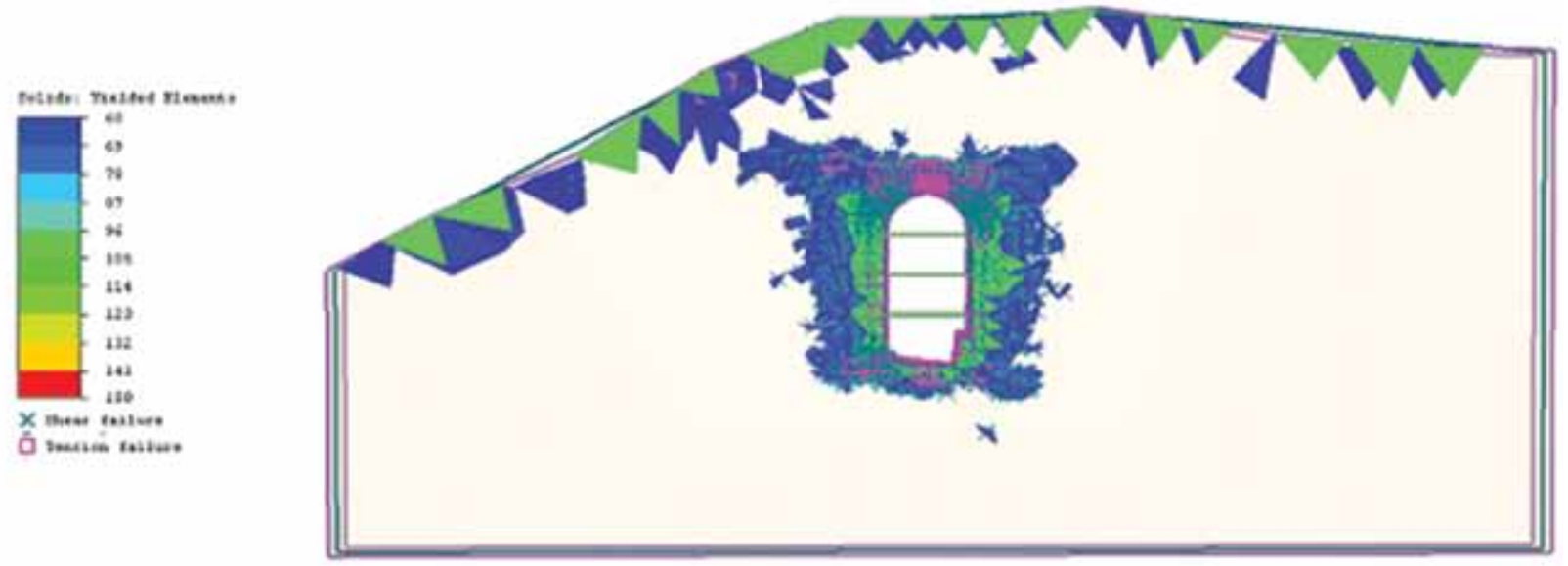

Figure 8: Analysis results on yielded elements in an unsupported state showing tensile and shear failure.

In RS-3D analysis the deformation magnitude ranged between 2 to $2.5 \mathrm{~cm}$ in the roof and wall area, which is less than that of RS-2D analysis. Yielding of bolts has shown similar results as of 2D analysis and no shotcrete liner element were observed yielded in the roof and wall, and total displacement was reduced to $1.5 \mathrm{~cm}$ only in the cavern wall facing away from the valley.

An analysis carried out using data inputs for the worst case scenario indicated that the rock mass around the cavern yielded in both shear and tension to an extent which may cause over break in the cavern roof and wall. The support elements provided were yielded beyond safe limits and the deformation on the cavern contour increased by 4 to 5 times. Therefore, it is highlighted here that selection of input variables plays an important role in analysing stability of the cavern.

\section{Discussions}

and Uncertainties

The maximum total deformation on the cavern without installed support was $8 \mathrm{~cm}$, which represents strain level of $0.35 \%$ Strain
Therefore, it is important that good quality control should be made while applying steel-fibre shotcrete.

It is highlighted that stability analysis made by using numerical models are dependent on the quality of input parameters. Hence, it is important to understand that uncertainties in input parameters will lead to inaccuracy in numerical model results. Keeping this in mind, a sensitivity analysis was carried out in order to see which parameters influence stability the most. This was done for the model without any rock support applied and with inputs representing both worst and best case scenario (Table 15).

\begin{tabular}{|l|c|c|}
\hline & $\begin{array}{c}\text { Yielded mesh } \\
\text { elements (\% increase) }\end{array}$ & $\begin{array}{c}\text { Maximum total } \\
\text { displacement [cm }]\end{array}$ \\
\hline Best estimate & 1342 & 5 \\
\hline Worst case & $2033(51)$ & 17 \\
\hline $\begin{array}{l}\text { W o r s t } \\
\text { case (Resi. } \\
\text { E-modulus) }\end{array}$ & $2176(62)$ & 56 \\
\hline
\end{tabular}

Table 15: Yielded mesh elements in percent for best and worst case scenario and maximum total displacement.

The quality of stability analysis depends on the accuracy of magnitude and direction of the in-situ stresses since failure zone that forms around the 
cavern is a function of far-field stresses, strength of rock mass and geometry of the opening. Projection of horizontal stresses into relevant cross section is a tricky task as it disregards shear stresses.

It is relatively difficult to achieve accurate calculations of the stress distribution using empirical and analytical approaches. Hoek and Brown (1980) proposed empirical method has shown comparable results to the numerical analysis (Table 16).

\begin{tabular}{|c|c|c|c|}
\hline \multicolumn{4}{|c|}{ Maximum Tangential Stress (MPa) } \\
\hline $\begin{array}{c}\text { Kirsch's Equation } \\
\text { (average) }\end{array}$ & $\begin{array}{c}\text { Hoek and Brown } \\
(\mathbf{1 9 8 0}) \text { (average) }\end{array}$ & $\begin{array}{c}\text { Numerical } \\
\text { results (average) }\end{array}$ & $\begin{array}{c}\text { Numerical results } \\
\text { (No disturbed zone) }\end{array}$ \\
\hline 17.5 & 23.57 & 23.94 & 30.43 \\
\hline
\end{tabular}

representative input parameters of in-situ stresses, rock mechanical properties and properties of support material. It is also highlighted that one should not rely only on a single stability analysis method while designing an underground cavern. It is recommended to use multiple approaches such as used in this manuscript.

Ajender Rathore has completed his MSc study in Hydropower Development in 2016 from the Norwegian University of Science and Technology (NTNU), Table 16: Comparis on of calculated stress distribution from analytical, empirical andTrondheim, Norway. He has three numerical methods.

Numerical analysis shows better results to describe depth of failure in comparison to equations for depth of failure. The assessment carried out suggests that the uncertainties involved in predicting failure extent in caverns located at shallow depths and near the toe slope is considerable. Hence, the equation for depth of failure should be applied carefully when planning powerhouse cavern near the toe slope.

Table 17 compares systematic rock bolt estimated using different analysis approaches showing certain level of uncertainty in the use of each approach. years of experience in construction supervision and design for Hydropower Projects in India.

Krishna Kanta Panthi is an Associate Professor in Geological Engineering at the Norwegian University of Science and Technology (NTNU) since 2008. He has long design, construction and research experience in tunnelling and hydropower development in the Himalaya and around the world. He is an author of many scientific papers published in internationally recognized journals and conferences.

Corresponding E-mail: krishna.panthi@ntnu.no

\begin{tabular}{|l|l|c|l|l|l|l|}
\hline Method of analysis & Location & \multicolumn{1}{c|}{ Type } & Length $(\mathbf{m})$ & \multicolumn{1}{c|}{ Spacing (m) } & Diameter (mm) & Tensile Capacity (MN) \\
\hline Unwedge & Roof & Fully grouted & 6 & $1.5 \times 1.5$ & 22 & 0.25 \\
\hline RMR system & Roof/wall & Fully grouted & $4 / 4$ & $2.0 \times 1.5$ & 20 & 0.25 \\
\hline Q-system & Roof/Wall & Fully grouted & $6 / 10$ & $1.7 \times 1.7 / 2.0 \times 2.0$ & - & - \\
\hline Numerical & Roof/Wall & Fully grouted & $6 / 10$ & $1.5 \times 1.5$ & 33 & 0.38 \\
\hline
\end{tabular}

Table 17: Comparison of Rock bolts from different approaches.

\section{References}

\section{Conclusions}

The stability assessment of the powerhouse cavern of Sach Khas hydropower project was carried out using empirical, analytical and numerical approaches and the results are compared. Empirical and analytical approaches have provided primary estimation rock support needed for a stable cavern. Such information is crucial for $2 \mathrm{D}$ and $3 \mathrm{D}$ numerical analysis, which will help enhance the quality of assessment since numerical analysis considers many different variables related to in-situ stress, rock mechanical properties and support material properties in one single basket. The analysis also indicated that appropriate settings within numerical software programs are essential including accurate geometrical information of the underground opening in focus, especially in regards with its location. The step-wise assessment and evaluation process should be followed to achieve good results for underground structure especially located in Himalayan geological conditions. Hence, the real uncertainty is related to the selection of

AECS. 2014. Report on hydraulic fracturing tests in the power house drift of proposed Sach Khas H.E. Project, Himachal Pradesh.A report produced by AECS Engineering and Geotechnical Services Pvt. Ltd

Barton N., Lien R. and Lunde J. 1974. Engineering classification of rock masses for the design of tunnel support. Rock mechanics, 6(4), pp. 189-236.

Bieniawski Z.T. 1989. Engineering rock mass classifications: a complete manual for engineers and geologists in mining, civil, and petroleum engineering. John Wiley \& Sons.

Gharavi M. and Shafiezadeh N. 2008. A Comparison of underground opening support design methods in jointed rock mass. International Journal of Engineering. Transactions B: Applications, 21(3), pp. 235-248.

Hammett R. and Hoek E. 1981. Design of large underground caverns for hydroelectric projects with particular reference to structurally controlled failure mechanisms. Proceedings: Recent Developments in Geotechnical Engineering for Hydro Projectspp, pp 192-206. Edited by Kulhawy FH.

Hoek E. 1994. Strength of rock and rock masses and 
displacements around underground openings. ISRM News Journal, vol. 2 (2), pp. 4-16.

Hoek E. 2001. Big Tunnels in Bad Rock: 2000 Terzaghi Lecture. ASCE Journal of Geotechnical and Geoenvironmental Engineering, vol. 127, pp. 726-740.

Hoek E. 2007. Practical rock engineering. Available in rocksciences webpage.

Hoek E. and Brown E.T. 1980. Underground excavations in rock. Institute of Mining and Metalurgy, London, $527 \mathrm{p}$.

Hoek E. and Moy D. 1993. Design of large powerhouse caverns in weak rock. Comprehensive rock engineering, pp. 85-110.

Larsen and Toubro. 2012a. Detailed Project Report Geology Report - Lab and Field Test Report for Sach Khas HEP $(260+7 \mathrm{MW})$, vol. III B.

Larsen and Toubro, 2012b. Detailed Project Report - Main Geological Report for Sach Khas HEP $(260+7 \mathrm{MW})$, vol. III A.
Nilsen B. and Palmström A., 2000. Engineering Geology and Rock Engineering: Handbook. Norwegian Group for Rock Mechanics, 249p.

Nilsen B. and Thidemann A. 1993. Rock Engineering: Hydropower Development Vol. 9. Norwegian Institute of Technology (NTH), 156p.

Panthi K. K., 2012. Evaluation of rock bursting phenomena in a tunnel in the Himalayas. Bulletin of Engineering Geology and the Environment, vol. 71: pp. 761-769

Panthi, K. K., 2016. Personal correspondence with supervisor.

VIKØrsta. 2012. CT-Bolt M33. Product sheet (http:// vikorsta.no/en/Products/Rock-support/CT-Bolt1/CTBolt-M33/).

DSI. 2016. DSI-Dywidag System International.ProductRocks Bolts/Solid Bars/High Strength Bar.www. dsiminingproducts.com . 